\title{
Bedrijfs- en verzekeringsartsen over ME/CVS: visie en praktijk
}

\author{
B.M. Blatter • R. van den Berg • D.J. van Putten
}

Samenvatting Het doel van het onderzoek was de visies en het handelen van bedrijfs- en verzekeringsartsen te inventariseren en met elkaar te vergelijken, ten aanzien van patiënten met myalgische encephalomyelitis/ chronisch vermoeidheidssyndroom (ME/CVS). De onderzoeksgroep bestond uit 110 bedrijfsartsen en 111 verzekeringsartsen. De gegevens werden via vragenlijsten verzameld. De belangrijkste conclusies van het onderzoek zijn dat het merendeel van de artsen vindt dat bij $\mathrm{ME} / \mathrm{CVS}$ sprake is van ziekte of gebrek, en dat de helft bij deze patiënten de diagnosecode N690 hanteert. Mogelijke oorzaken worden vooral gezocht in stoornissen in energiehuishouding (vaker door de bedrijfsartsen) en 'de psychische hoek' (vaker door de verzekeringsartsen). Behandelingen of begeleidingsrichtingen waar de artsen dan ook het meest in zien, zijn activeren van de patiënten (vooral bedrijfsartsen) en psychologische of cognitieve gedragstherapie (vooral verzekeringsartsen). Een meerderheid van de bedrijfsartsen heeft behoefte aan een richtlijn voor sociaal-medische begeleiding van patiënten met ME/CVS; (onofficiële) richtlijnen worden op dit moment sporadisch gebruikt.Verzekeringsartsen hebben relatief minder behoefte aan een beoordelingsrichtlijn.

Keywords chronisch vermoeidheidssyndroom . opinieonderzoek · sociaal-geneeskundigen

B.M. Blatter $(\square)$

PersonaliaBirgitte M. Blatter, Ruurt van den Berg, Dick van Putten werken allen bij TNO Kwaliteit van Leven in

Hoofddorp.CorrespondentieadresDr. Birgitte M. Blatter, TNO Kwaliteit van Leven, Postbus 718, 2130 AS Hoofddorp.E-mail: b.blatter@arbeid.tno.nl.Belangenconflicten: geen gemeldFinanciële ondersteuning: UWV

\section{Inleiding}

In het recentelijk uitgekomen rapport van de Gezondheidsraad over ME/CVS1 wordt geconcludeerd dat CVS een reële, ernstige invaliderende aandoening is, waar vermoedelijk tussen de 30.000 en 40.000 mensen in Nederland aan lijden. Tevens wordt geconcludeerd dat strikte opvattingen over lichamelijke en psychische oorzaken de relatie tussen arts en patiënt onder druk zetten en dat adequate zorg richtlijnen voor diagnostiek en begeleiding vereist. Het bepalen van de omvang van $\mathrm{ME} / \mathrm{CVS}$ en het bepalen van trends wat betreft een toename of afname van $\mathrm{ME} / \mathrm{CVS}$ is moeilijk, omdat zowel huisartsen als bedrijfs- en verzekeringsartsen vaak terughoudend zijn om de diagnose te stellen. Dit lijkt het geval ondanks dat $\mathrm{ME}$ is opgenomen in de International Classification of Diseases 2 en ondanks dat het deel uitmaakt van diagnosecodes voor bedrijfsen verzekeringsartsen. 3 Bij bedrijfsartsen zou dit te maken kunnen hebben met onbekendheid met de criteria, of een aversie tegen het stellen van de diagnose $\mathrm{ME} /$ CVS omdat effectieve behandeling- en reïntegratiestrategieën afwezig zijn (hoewel het advies van de Gezondheidsraad dit tegenspreekt). Bij verzekeringsartsen zou de interpretatie van het Medisch Arbeidsongeschiktheidscriterium van de Wet op de arbeidsongeschiktheids verzekering (WAO) mogelijkerwijs een rol kunnen spelen.

- Volgens driekwart van de artsen is er bij ME/CVS sprake van ziekte of gebrek.

- Minder dan de helft van de artsen gebruikt de diagnosecode N690.

- Oorzaken worden voornamelijk gezocht in stoornissen in de energiehuishouding en in psychische factoren. 
- Verzekeringsartsen vinden psychische stoornissen relatief vaker een oorzaak voor $\mathrm{ME} / \mathrm{CVS}$; bedrijfsartsen relatief vaker (onbekende) lichamelijke stoornissen.

- De artsen noemen voornamelijk activeren, cognitieve (gedrags)therapie en psychologische/ psychotherapeutische behandeling als mogelijk gunstige behandeling of wijze van begeleiding.

- Bedrijfsartsen verwijzen voor therapie relatief het vaakst naar een psycholoog.

Het doel van het huidige onderzoek, uitgevoerd voordat de Gezondheidsraad zijn advies opstelde, bestond eruit inzicht te verkrijgen in de manier waarop bedrijfs- en verzekeringsartsen aankijken tegen $\mathrm{ME} /$ CVS en handelen bij ME/CVS. De volgende vragen zijn gesteld:

1. Wat zijn de visies en meningen van bedrijfs- en verzekeringsartsen over de diagnose, beoordeling en behandeling van $\mathrm{ME} / \mathrm{CVS}$ ?

2. In hoeverre verschillen deze meningen?

3. Hoe oordelen verzekeringsartsen bij de keuring van patiënten met $\mathrm{ME} / \mathrm{CVS}$ en hoe verwijzen en adviseren bedrijfsartsen?

\section{Populatie en methoden}

De onderzoeksgroep bestond uit een aselecte steekproef van 300 bedrijfsartsen, lid van de NVAB, en 300 verzekeringsartsen, aangesloten bij de NVVG. In oktober en november 2001 zijn vragenlijsten met een begeleidende brief en antwoordenveloppe naar de huisadressen van al deze artsen gestuurd; bij de verzekeringsartsen was tevens een brief van de NVVG bijgesloten.

De vragenlijsten bevatten ongeveer 35 vragen, deels met voorgestructureerde antwoordcategorieën en deels met ruimte voor een toelichting. Een deel van de vragen ging over de visie van de arts over $\mathrm{ME} / \mathrm{CVS}$ in het algemeen; een deel over de praktijk ten aanzien van $\mathrm{ME} /$ CVS-patiënten die men het jaar voorafgaand aan het onderzoek had gezien of begeleid. De vragenlijsten voor bedrijfs- en verzekeringsartsen waren voor een groot deel overlappend.

Beschrijvende analyses zijn uitgevoerd. Bij verschillen in percentages tussen bedrijfs- en verzekeringsartsen worden tevens $p$-waardes gepresenteerd wanneer deze kleiner zijn dan 0,05. Deze $p$-waardes zijn berekend door middel van デ2-toetsen bij het vergelijken van de totale verdelingen.

\section{Resultaten}

Respons en beschrijving van de onderzoekspopulatie

Van de 600 aan bedrijfsartsen en verzekeringsartsen verzonden lijsten kwamen er 30 terug omdat de arts niet als zodanig werkzaam was. Zestien lijsten waren te laat ingestuurd om nog in de analyses te kunnen worden opgenomen. Uiteindelijk waren 110 vragenlijsten van bedrijfsartsen (netto respons 39\%) geschikt voor dataanalyse en 111 vragenlijsten van verzekeringsartsen $(40 \%)$.

Bijna driekwart van de artsen in de onderzoeksgroep was man. De gemiddelde leeftijd van alle respondenten was 45 jaar en men was gemiddeld 13 jaar als bedrijfs- of verzekeringsarts werkzaam. Van de verzekeringsartsen was het grootste deel werkzaam bij het toenmalige GAK $(50 \%)$. Dertig procent was bij een andere uitvoeringsinstelling werkzaam. De overigen rapporteerden dat ze als zelfstandige werkzaam waren of bij een particulier bureau, een arbodienst of een reïntegratiebedrijf. Van de bedrijfsartsen was 34\% werkzaam bij Arbo Unie en 18\% bij een interne arbodienst.

\section{Visie met betrekking tot ME/CVS}

Volgens $73 \%$ van de artsen was er bij ME/CVS sprake van ziekte of gebrek (tabel 1). Twintig procent stelde zelf wel eens de diagnose ME/CVS, waarvan slechts een klein deel de criteria van Holmes4 of Fukuda5 volgde (13\%). $\mathrm{Bij}$ de overigen is het onduidelijk of zij diagnosecriteria toepasten en zo ja, welke.

Acht omschrijvingen van ME/CVS werden aan de artsen voorgelegd, waarvan zij konden aangeven of ze daar (helemaal) mee eens waren, deels mee eens en deels niet mee eens, of (volstrekt) niet mee eens. De omschrijving van ME/CVS waar de meeste artsen het (helemaal) mee eens waren $(34 \%)$, was 'een ziekte of verzameling van ziektes waarvan de oorzaak (nog) onbekend is'. Bedrijfsartsen vonden dit vaker dan verzekeringsartsen. Daarna volgde een stoornis in de energiehuishouding: $23 \%$ was het hiermee eens. Ook een stoornis in de energiehuishouding werd vaker door bedrijfsartsen dan door verzekeringsartsen onderschreven. Verschillen tussen artsen wat betreft 'milde vorm van depressie' en 'hypochondrie' uitten zich juist doordat meer bedrijfsartsen het niet met deze stellingen eens waren; evenveel artsen waren het wel met de stelling eens. Uit de soms zowel hoge percentages 'volstrekt mee eens' als hoge percentages 'volstrekt (niet) mee eens' blijkt dat de meningen ook binnen de beroepsgroepen nogal eens uiteen lopen.

Vervolgens werd gevraagd welke factoren ook konden bijdragen aan het ontstaan van ME/CVS. Het meest 
Tabel 1 Visie van verzekeringsartsen (va's) en bedrijfsartsen (ba's) over ME/CVS in het algemeen

\begin{tabular}{|c|c|c|c|c|}
\hline & totaal $(n=221)$ & $\mathrm{va}(\mathrm{n}=111)$ & $\mathrm{ba}(\mathrm{n}=110)$ & p-waarde $<0,10$ \\
\hline Is er volgens u sprake van ziekte of gebrek? & $73 \%$ & $72 \%$ & $73 \%$ & + \\
\hline \multicolumn{4}{|l|}{ Stelt u zelf wel eens de diagnose ME/CVS? } & - \\
\hline $\mathrm{Ja}$ & $20 \%$ & $23 \%$ & $17 \%$ & \\
\hline Nee & $43 \%$ & $41 \%$ & $45 \%$ & \\
\hline Sluit aan bij diagnose behandelend arts & $37 \%$ & $36 \%$ & $38 \%$ & \\
\hline \multicolumn{4}{|l|}{ Welke diagnosecriteria gebruikt $u$ ? } & 0,06 \\
\hline Holmes4 & $8 \%$ & $4 \%$ & $12 \%$ & \\
\hline Fukuda5 & $5 \%$ & $0 \%$ & $12 \%$ & \\
\hline Anders & $33 \%$ & $22 \%$ & $47 \%$ & \\
\hline Onbekend & $45 \%$ & $61 \%$ & $24 \%$ & \\
\hline \multicolumn{4}{|l|}{ Beschouwt u ME/CVS als een milde vorm van depressie?* } & 0,03 \\
\hline (Helemaal) mee eens & $19 \%$ & $18 \%$ & $20 \%$ & \\
\hline (Volstrekt) niet mee eens & $22 \%$ & $15 \%$ & $29 \%$ & \\
\hline \multicolumn{4}{|l|}{ Beschouwt u ME/CVS als een vorm van hypochondrie?* } & - \\
\hline (Helemaal) mee eens & $18 \%$ & $18 \%$ & $18 \%$ & \\
\hline (Volstrekt) niet mee eens & $32 \%$ & $27 \%$ & $38 \%$ & \\
\hline \multicolumn{4}{|l|}{ Beschouwt u ME/CVS als een onbekende somatische ziekte?* } & 0,00 \\
\hline (Helemaal) mee eens & $11 \%$ & $4 \%$ & $19 \%$ & \\
\hline (Volstrekt) niet mee eens & $55 \%$ & $58 \%$ & $52 \%$ & \\
\hline \multicolumn{4}{|l|}{ Beschouwt u ME/CVS als een stoornis van het immuunsysteem?* } & 0,06 \\
\hline (Helemaal) mee eens & $5 \%$ & $3 \%$ & $8 \%$ & \\
\hline (Volstrekt) niet mee eens & $64 \%$ & $72 \%$ & $56 \%$ & \\
\hline \multicolumn{4}{|c|}{ Beschouwt u ME/CVS als een stoornis van het autonoom zenuwstelsel?* } & - \\
\hline (Helemaal) mee eens & $4 \%$ & $4 \%$ & $4 \%$ & \\
\hline (Volstrekt) niet mee eens & $68 \%$ & $74 \%$ & $61 \%$ & \\
\hline \multicolumn{4}{|c|}{ Beschouwt u ME/CVS als een stoornis in de energiehuishouding?* } & 0,03 \\
\hline (Helemaal) mee eens & $23 \%$ & $16 \%$ & $31 \%$ & \\
\hline \multicolumn{5}{|l|}{ (Volstrekt) niet mee eens 28\% 34\% 22\% } \\
\hline \multicolumn{4}{|c|}{ Beschouwt u ME/CVS als een gevolg van virale of bacteriële infectie?* } & 0,01 \\
\hline (Helemaal) mee eens & $8 \%$ & $6 \%$ & $11 \%$ & \\
\hline (Volstrekt) niet mee eens & $42 \%$ & $52 \%$ & $30 \%$ & \\
\hline \multicolumn{4}{|l|}{ Beschouwt u ME/CVS als een oorzaak (nog) onbekend?* } & 0,01 \\
\hline (Helemaal) mee eens & $34 \%$ & $26 \%$ & $43 \%$ & \\
\hline (Volstrekt) niet mee eens & $26 \%$ & $35 \%$ & $16 \%$ & \\
\hline \multicolumn{4}{|l|}{$\begin{array}{l}\text { Welke factoren kunnen bijdragen aan ontstaan ME/CVS? } \\
\text { [meer antwoorden mogelijk] }\end{array}$} & 0,00 \\
\hline (Gestoorde) persoonlijkheid & $72 \%$ & $82 \%$ & $62 \%$ & \\
\hline Stressvolle gebeurtenis of periode privé & $71 \%$ & $74 \%$ & $68 \%$ & \\
\hline Stressvolle arbeidsomstandigheden & $55 \%$ & $59 \%$ & $51 \%$ & \\
\hline Traumatische ervaring in jeugd & $38 \%$ & $41 \%$ & $34 \%$ & \\
\hline Blootstelling schadelijke/giftige stoffen & $14 \%$ & $15 \%$ & $12 \%$ & \\
\hline \multicolumn{4}{|l|}{ Heeft u kennis van de medische stand van zaken? } & 0,01 \\
\hline $\mathrm{Ja}$ & $28 \%$ & $38 \%$ & $18 \%$ & \\
\hline Enigszins & $65 \%$ & $58 \%$ & $71 \%$ & \\
\hline Nee & $7 \%$ & $4 \%$ & $11 \%$ & \\
\hline Is $\mathrm{u}$ behandeling bekend die mogelijk gunstig is? & $64 \%$ & $77 \%$ & $52 \%$ & 0,00 \\
\hline Heeft u behoefte aan kennis hierover? & $60 \%$ & $59 \%$ & $62 \%$ & - \\
\hline
\end{tabular}

"Antwoordcategorie 'deels mee eens en deels niet mee eens' is niet in de tabel gepresenteerd. 
genoemd werden: (gestoorde) persoonlijkheid (72\%), stressvolle gebeurtenis of periode in privé-leven $(71 \%)$ en belastende stressvolle arbeidsomstandigheden (55\%). Verzekeringsartsen noemden (gestoorde) persoonlijkheid vaker dan bedrijfsartsen.

Ook werden enkele vragen gesteld over kennis en behoefte aan kennis over ME/CVS. Slechts 7\% gaf aan dat zij geen kennis hadden van de medische stand van zaken ten aanzien van ME/CVS; het grootste deel rapporteerde er enigszins verstand van te hebben. Verzekeringsartsen gaven vaker dan de bedrijfsartsen aan dat zij kennis van de medische stand van zaken hadden: $38 \%$ vergeleken met $18 \%$. Van de artsen gaf vervolgens $64 \%$ aan dat zij behandelingen of begeleidingen kenden die mogelijk gunstig waren voor het beloop van ME/CVS, verzekeringsartsen $(77 \%)$ vaker dan bedrijfsartsen $(52 \%)$. Behandelingen die in een open vraag door bedrijfsartsen het meest genoemd werden, waren het geleidelijk activeren en opbouwen van de conditie $(34 \%)$ en cognitieve (gedrags)therapie $(21 \%)$. Medicijnen, alternatieve geneeswijzen, multifactoriële aanpak en overige psychologische behandelingen werden enkele malen genoemd door bedrijfsartsen. Van de verzekeringsartsen noemde $45 \%$ cognitieve (gedrags)therapie, $15 \%$ psychologische of psychotherapeutische behandeling en $14 \%$ het opbouwen van de conditie en activeren van de patiënt.

Van de verzekeringsartsen gaf $33 \%$ aan dat er een (informele) afspraak op de uitvoeringsinstelling bestond hoe cliënten met ME/CVS te beoordelen (cijfers niet in tabel gepresenteerd). Op de vraag om dit te specificeren, noemden acht verzekeringsartsen van de $36(22 \%)$ de Richtlijn Medisch Arbeidsongeschiktheidscriterium (MAOC), zes artsen (17\%) het checken van de consistentie/het dagverhaal, en drie artsen $(8 \%)$ het omzetten van stoornissen in beperkingen. Een minderheid van alle verzekeringsartsen $(44 \%)$ vond dat er een apart protocol of richtlijn moest komen voor de beoordeling van cliënten. Eenderde van de verzekeringsartsen $(35 \%)$ achtte het voor de beoordeling van belang dat de diagnose $\mathrm{ME} /$ CVS was gesteld.Van de bedrijfsartsen gaf $9 \%$ aan dat een beleid aanwezig was voor de sociaal-medische begeleiding. Op de vraag of men behoefte had aan een specifieke richtlijn voor ME/CVS antwoordde $61 \%$ positief. De behoefte aan een dergelijke richtlijn (voor zowel bedrijfs- als verzekeringsartsen) was overigens niet gerelateerd aan de visie van de arts of er bij ME/CVS sprake is van ziekte of gebrek.

Activiteiten uitgevoerd bij cliënten met ME/CVS het afgelopen jaar

Aan bedrijfsarts en verzekeringsarts is gevraagd welke diagnoses gesteld werden bij de cliënten die zij het afgelopen jaar gezien hadden (tabel 2). De diagnosecode voor ME/CVS volgens de CAS-code systematiek, N690 ('vermoeidheidssyndroom na virale infectie'), werd door iets minder dan de helft van de ondervraagde artsen ook werkelijk gebruikt; door verzekeringsartsen vaker dan door bedrijfsartsen. De artsen die vonden dat er bij ME/CVS sprake was van ziekte of gebrek gebruikten de code overigens beduidend vaker $(78 \%)$ dan de artsen die vonden dat ME/CVS geen ziekte of gebrek was $(45 \%, p$ waarde 0,00). Eveneens de helft gebruikte een andere CAS-code, met name uit de A-rubriek (algemene klachten, moeheid) en de P-rubriek (psychologische en psychiatrische klachten/aandoeningen). De redenen om de N690 code niet te gebruiken, waren voornamelijk dat men ME/CVS niet als een zuivere, werkbare diagnose beschouwde, de benaming niet juist vond, de term te stigmatiserend of invaliderend vond, het een nietszeggende code betrof, of de aandoening niet neurologisch vond.

Aan de verzekeringsarts is onder andere gevraagd wat het oordeel over de belastbaarheid was bij de cliënten die zij het afgelopen jaar gezien hadden (tabel 3). Er waren weinig verzekeringsartsen die de cliënten die zij gezien hadden volledig belastbaar achtten of helemaal niet belastbaar. De meeste verzekeringsartsen gaven aan dat de cliënten gedeeltelijk belastbaar waren $(69 \%$ alle/ meeste gevallen, $25 \%$ sommige gevallen). Deze beoordeling bleek sterk gerelateerd te zijn aan de visie van de arts of bij ME/CVS sprake is van ziekte of gebrek. Artsen die ME/CVS geen ziekte of gebrek vonden, achtten de patiënten vaker volledig belastbaar $(p<0.00$, niet in tabel).Van de verzekeringsartsen was $22 \%$ op enige wijze betrokken geweest bij de reïntegratie naar werk bij de betreffende cliënten.

Ook is aan de bedrijfsartsen gevraagd wat zij voor acties uitvoerden bij hun cliënten met

Tabel 2 Gehanteerde diagnosecode bij cliënten met ME/CVS in afgelopen jaar, verzekeringsartsen (va's) en bedrijfsartsen (ba's)

\begin{tabular}{|c|c|c|c|c|}
\hline & totaal $(n=221)$ & va's $(n=111)$ & ba's $(\mathrm{n}=110)$ & p-waarde $<0,10$ \\
\hline \multicolumn{5}{|c|}{ Welke diagnosecode gebruikt $u$ ? [meerdere antwoorden mogelijk] } \\
\hline N690 & $46 \%$ & $51 \%$ & $40 \%$ & 0,05 \\
\hline Andere code & $48 \%$ & $52 \%$ & $44 \%$ & \\
\hline Geen code & $14 \%$ & $10 \%$ & $17 \%$ & \\
\hline
\end{tabular}


Tabel 3 Uitgevoerde activiteiten (oordeel belastbaarheid) bij cliënten met ME/CVS in afgelopen jaar, verzekeringsartsen (va's)

va's $(\mathrm{n}=106)$

Wat was uw oordeel over belastbaarheid*

Volledig

Alle/meeste gevallen $\quad 10 \%$

Nooit/niet beantwoord $\quad 60 \%$

Gedeeltelijk

Alle/meeste gevallen

$69 \%$

Niet

Nooit/niet beantwoord 7\%

Alle/meeste gevallen $\quad 5 \%$

Nooit/niet beantwoord $\quad 62 \%$

Bent $u$ betrokken geweest bij de reïntegratie?

$\mathrm{Ja}$

$22 \%$

Nee

Niet beantwoord

"Antwoordcategorie ‘sommige gevallen' niet gepresenteerd.

Tabel 4 Uitgevoerde activiteiten bij cliënten met ME/CVS in afgelopen jaar, bedrijfsartsen (ba's)

\begin{tabular}{lr}
\hline & ba's $(\mathrm{n}=98)$ \\
\hline $\begin{array}{l}\text { Welke acties heeft u uitgevoerd in relatie tot diagnose?[meer } \\
\text { antwoorden mogelijk] }\end{array}$ & $32 \%$ \\
Geen acties ondernomen & $24 \%$ \\
Contact gehad met huisartsen & $20 \%$ \\
Contact gehad met specialisten of hulpverleners & $15 \%$ \\
Verwezen naar psycholoog & $12 \%$ \\
Verwezen naar huisarts & $8 \%$ \\
Verwezen naar andere specialist of hulpverlener & $6 \%$ \\
Verwezen naar internist & $6 \%$ \\
Zelf onderzocht & $5 \%$ \\
Verwezen naar psychiater & \\
Welke acties heeft u uitgevoerd in relatie tot therapie? [meer & \\
$\quad$ antwoorden mogelijk] & \\
Verwezen naar psycholoog & $21 \%$ \\
Begeleid met gesprekken & $21 \%$ \\
Contact gehad met huisartsen & $19 \%$ \\
Verwezen naar andere specialist of hulpverlener & $11 \%$ \\
Contact gehad met specialisten of hulpverleners & $10 \%$ \\
Verwezen naar internist & $7 \%$ \\
Verwezen naar psychiater & $7 \%$ \\
Zelf behandeld & $3 \%$ \\
\hline
\end{tabular}

vermoeidheidsklachten of ME/CVS in het jaar voorafgaand aan het onderzoek (tabel 4). Eenderde van de bedrijfsartsen gaf aan (32\%) geen acties ondernomen te hebben voor nadere diagnostiek. Een kwart had contact gehad met de huisarts van één of meerdere cliënten, $20 \%$ met een specialist of andere hulpverlener. De meeste bedrijfsartsen bleken hun cliënten te adviseren naar een psycholoog te gaan (15\%), 12\% adviseerde hun cliënten naar de huisarts te gaan. Acties in relatie tot therapie waren voornamelijk het verwijzen naar een psycholoog $(21 \%)$, het zelf begeleiden van de cliënten $(21 \%)$ en het hebben van contact met de huisarts (19\%).

\section{Adviezen voor werkaanpassingen}

Gevraagd is welke werkaanpassingen geadviseerd waren bij nog werkende en bij de reeds verzuimende cliënten met ME/CVS-klachten. De aanpak bij beide groepen verschilde niet noemenswaardig; daarom is er voor gekozen alleen de adviezen voor de werkende CVS-patiënten te presenteren in tabel 5. Werkaanpassingen in de arbeidsduur per dag of per week werden het meest geadviseerd, daarna aanpassingen van de inhoud en de organisatie van het werk. Uit tabel 4 is af te leiden dat de adviezen redelijk eensluidend waren binnen de groep bedrijfsartsen, behalve ten aanzien van de arbeidsomstandigheden: eenderde adviseerde aanpassing van arbeidsomstandigheden aan alle of de meeste cliënten en eenkwart juist aan (bijna) niemand. De meeste bedrijfsartsen adviseerden de cliënt om gedeeltelijk aan het werk te gaan $(73 \%$ adviseerde dit aan alle of aan de meeste cliënten), een kwart vond dat alle of de meeste cliënten weer volledig moesten gaan werken en slechts $6 \%$ gaf aan dat alle of de meeste cliënten niet konden werken.

De helft van de bedrijfsartsen had alle of de meeste werknemers met ME/CVS-klachten begeleid na reïntegratie en $84 \%$ had contact gehad met de werkgever. Het doel van dat contact was in de meeste gevallen het adviseren van werkaanpassingen $(58 \%)$ en slechts in zeer zeldzame gevallen advies met betrekking tot loondoorbetaling of ontslagadvies.

\section{Discussie}

Tot nu toe bestonden er slechts weinig tot geen onderzoekscijfers over de visie en handelingen van bedrijfs- en verzekeringsartsen t.a.v. ME/CVS. Doel van het huidige onderzoek was inzicht te verkrijgen in dit onderwerp. Hiervoor hebben we vragenlijsten gestuurd aan bedrijfsen verzekeringsartsen. 
Tabel 5 Adviezen aan cliënten met ME/CVS in afgelopen jaar, bedrijfsartsen (ba's)

ba’s $(\mathrm{n}=98)$

Welke werkaanpassingen heeft u geadviseerd voor werkenden?**

Arbeidsduur per dag

Arbeidsduur per week

Inhoud werk

Organisatie werk

Arbeidsomstandigheden

Kwalificatieniveau werknemer

Arbeidsvoorwaarden

Wat voor advies heeft u gegeven m.b.t. werkhervatting?*

Volledig

Gedeeltelijk

Niet werken

Heeft $u$ de werknemer begeleid na reïntegratie?*
Alle/meeste

Nooit/niet beantwoord

Alle/meeste

Nooit/niet beantwoord

Alle/meeste

Nooit/niet beantwoord

Alle/meeste

Nooit/niet beantwoord

Alle/meeste

Nooit/niet beantwoord

Alle/meeste

Nooit/niet beantwoord

Alle/meeste

Nooit/niet beantwoord

Alle/meeste

$25 \%$

Nooit/niet beantwoord

Alle/meeste

$38 \%$

$73 \%$

Nooit/niet beantwoord

Alle/meeste

oit/niet beantwoord

le/meeste

$9 \%$

oit/niet beantwoord

"Antwoordcategorie 'sommige gevallen' niet gepresenteerd; samen met alle/meeste en nooit/niet beantwoord is dit $100 \%$.

Tabel 6 Contact met werkgevers bij cliënten met ME/CVS in afgelopen jaar, bedrijfsartsen (ba's)

\begin{tabular}{|c|c|}
\hline & ba's $(n=98)$ \\
\hline \multicolumn{2}{|l|}{ Contact met werkgevers? } \\
\hline $\mathrm{Ja}$ & $84 \%$ \\
\hline \multicolumn{2}{|l|}{$\begin{array}{l}\text { Wat was het doel van het contact? } \\
\text { [meerdere antwoorden mogelijk] }\end{array}$} \\
\hline Adviseren werkaanpassingen & $58 \%$ \\
\hline Anders & $12 \%$ \\
\hline Advies met betrekking tot loondoorbetaling & $3 \%$ \\
\hline Ontslagadvies & $1 \%$ \\
\hline Niet beantwoord & $26 \%$ \\
\hline
\end{tabular}

Voordat de resultaten worden besproken willen we enkele opmerkingen maken met betrekking tot de methodologische beperkingen van dit onderzoek. Zo was de respons op dit onderzoek $40 \%$. Ondanks dat dit voor artsen een niet ongewoon percentage is, is het niet duidelijk of er selectieve repons is opgetreden. Het is dus de vraag of de andere $60 \%$ van de artsen niet meegedaan heeft omdat men ME/CVS niet als ziekte erkent, of omdat men het druk had of in het algemeen 'vragenlijst-moe' was. Omdat er geen non-respons onderzoek gedaan is, kunnen we geen uitspraak doen over de representativiteit van de onderzoekspopulatie.Tevens moet rekening gehouden worden met het feit dat de gegevens drie jaar geleden verzameld zijn. Mogelijk zijn daarna veranderingen opgetreden.

Uit de resultaten blijkt dat een kwart van zowel de bedrijfs- als de verzekeringsartsen vindt dat er bij ME/ CVS geen sprake is van ziekte of gebrek, minder dan in het onderzoek van Bakker en Van der Werf,6 waarin onder verzekeringsartsen een percentage van $40 \%$ werd gevonden. De helft van de bedrijfs- en verzekeringsartsen gebruikt de diagnosecode N690 ('vermoeidheidssyndroom na virale infectie') bij het registreren van de diagnose van de patiënt. Door de resterende helft worden codes voor algemene klachten en moeheid en codes voor psychische klachten en aandoeningen gebruikt. Manders en Nijs7 concludeerden in hun onderzoek eveneens dat het recht op een WAO-uitkering meestal wordt toegekend op grond van andere diagnoses dan ME/CVS. Daarbij is echter niet duidelijk in hoeverre die andere codes comorbiditeit betreffen of op een poging duiden de code N690 te ondervangen. Dit belemmert uiteraard het verkrijgen van valide cijfers over verzuim en arbeidsongeschiktheid ten gevolge van ME/CVS. 
Wat betreft de mening van de artsen met betrekking tot de oorzaken van ME/CVS, valt op dat de meeste bedrijfsen verzekeringsartsen denken aan een stoornis in de energiehuishouding als oorzaak, wat zowel kan refereren aan symptomatologie als aan processen op cellulair niveau. Daarnaast vinden veel bedrijfs- en verzekeringsartsen dat depressie een oorzaak is voor ME/CVS en ook hypochondrie wordt veel als oorzaak genoemd. Ook vindt een groot deel van de artsen dat de (gestoorde) persoonlijkheid en het hebben meegemaakt van een stressvolle gebeurtenis of periode in het privé-leven tot het ziektebeeld $\mathrm{ME} / \mathrm{CVS}$ kunnen leiden. Uit deze laatste bevindingen kan geconcludeerd worden dat de artsen de oorzaken voor een groot deel in de psychische of psychosociale hoek zoeken. Hiermee samenhangend blijkt dat bedrijfsartsen voor therapie relatief het vaakst doorverwijzen naar de psycholoog en noemen verzekeringsartsen vooral cognitieve gedragstherapie als mogelijk gunstige behandeling.

Wat betreft de gepercipieerde oorzaken van $\mathrm{ME} / \mathrm{CVS}$ zijn er duidelijk verschillen tussen bedrijfs- en verzekeringsartsen: zo denken verzekeringsartsen vaker dan bedrijfsartsen dat ME/CVS te maken heeft met een gestoorde persoonlijkheid, stress of depressie. De bedrijfsartsen zoeken oorzaken voor ME/CVS relatief iets vaker in de somatische hoek: ze vinden vaker dan verzekeringsartsen dat ME/CVS een onbekende (somatische) ziekte is of een stoornis in de energiehuishouding. De reden voor deze verschillen kunnen wij niet verklaren maar hangt mogelijk samen met het stadium waarin de werknemers gezien worden door bedrijfs- en verzekeringsartsen: vroeg in de verzuimperiode, respectievelijk bij de WAO-poort, als al sprake is van een langdurige uitval uit het werk. De verzekeringsartsen zien dus niet de groep patiënten die binnen ca. 8-9 maanden weer terugkeren naar werk of anderszins hun arbeidssituatie beëindigen.

Wanneer we de visie van de bedrijfs- en verzekeringsartsen vergelijken met die van huisartsen 8 blijkt dat huisartsen hypochondrie minder vaak noemen (9\%) als oorzaak van $\mathrm{ME} / \mathrm{CVS}$ dan bedrijfs- en verzekeringsartsen $(18 \%)$, en dat huisartsen ME/CVS juist vaker (17\%) een onbekende somatische ziekte noemen dan bedrijfsen verzekeringsartsen $(11 \%)$. Huisartsen beschouwen een infectie iets vaker $(13 \%)$ dan bedrijfs- en verzekeringsartsen (8\%) als oorzaak van ME/CVS.

Wanneer we de meningen van de artsen vergelijken met die van de patiënten zelf,9 blijken daar nog grotere verschillen tussen te bestaan. Zo noemen de ME/CVSpatiënten een stoornis van het immuunsysteem en virus of bacterie het vaakst, terwijl deze oorzaken door bedrijfs- en verzekeringsartsen vrijwel niet genoemd werden. Het ligt voor de hand dat deze discrepantie de communicatie en het onderlinge begrip tussen arts en patiënt niet bevordert en dat er aandacht besteed moet worden aan het opheffen ervan. Hoewel er over dé oorzaken van ME/CVS nog niet veel bekend is, blijkt dat antidepressiva niet aanslaan bij een subgroep van depressieve ME/CVS-patiënten, 10 wat suggereert dat processen die ten grondslag liggen aan depressie bij ME/CVS anders zijn dan die in patiënten met depressieve stoornissen. Uit een scriptie van de vakgroep Medische Psychologie uit Maastricht blijkt dat ME/CVS-patiënten eveneens van een groep hypochondrie patiënten verschillen wat betreft gezondheidsattitude, gezondheidswaardering en beheersingsoriëntatie.11

Tweederde van de uvi's maakte geen afspraken over de beoordeling van ME/CVS door verzekeringsartsen. Over de behoefte aan dergelijke afspraken of beoordelingsrichtlijnen zijn de verzekeringsartsen niet eensgezind: iets meer dan de helft van de artsen heeft geen behoefte aan een beoordelingsrichtlijn, iets minder dan de helft vindt dit wel een goed idee.Volgens Bakker en Van der Werf6 worden de richtlijnen die er nu zijn voor arbeidsongeschiktheidsbeoordelingen, wel gebruikt, maar blijkbaar zeer verschillend geïnterpreteerd. Een aparte richtlijn voor ME/CVS (of voor andere groepen patiënten) vond driekwart van de verzekeringsartsen toen niet nodig, met als reden dat men patiënten gelijk wilde behandelen. In het Gezondheidsraadrapport 1 wordt wel gepleit voor dergelijke richtlijnen.

De conclusies samenvattend kunnen we stellen dat volgens driekwart van de artsen er bij ME/CVS sprake is van ziekte of gebrek; minder dan de helft van de artsen de diagnosecode N690 gebruikt; oorzaken voornamelijk worden gezocht in stoornissen in de energiehuishouding en in psychische factoren; verzekeringsartsen psychische stoornissen relatief vaker een oorzaak vinden voor $\mathrm{ME} / \mathrm{CVS}$ en bedrijfsartsen relatief vaker (onbekende) lichamelijke stoornissen. Wat betreft de begeleiding/ behandeling worden activeren, cognitieve (gedrags)therapie en psychologische/psychotherapeutische behandeling als mogelijk gunstige behandelingen of begeleidingen genoemd. Verder blijkt dat bedrijfsartsen voor therapie relatief het vaakst naar een psycholoog verwijzen en bij werkaanpassingen vaak adviseren om de arbeidsduur per dag of per week aan te passen. Verzekeringsartsen oordelen dat de meeste cliënten die men ziet gedeeltelijk belastbaar zijn; minder dan de helft van de verzekeringsartsen heeft behoefte aan een richtlijn voor de beoordeling van arbeidsongeschiktheid van ME/CVS-patiënten.

\section{Literatuur}

1. Gezondheidsraad. Het chronische-vermoeidheidssyndroom. Den Haag: Gezondheidsraad, 2005; publicatie nr 2005/02. 
2. World Health Organization. International Statistical Classification of Diseases and Related Health Problems. Tenth Revision, ICD-10. Genève: World Health Organization, 1992, vol. 1, pag. 424, G93.3.

3. Lisv. CAS Classificaties voor Arbo en SV. Utrecht: Voorlichtingscentrum Sociale Verzekering, 1997.

4. Holmes GP, Kaplan JE, Gantz NM et al. Chronic fatigue syndrome: a working case definition. Ann Intern Med 1988; 108(3): 387-389.

5. Fukuda K, Straus S, Hickie I, et al. The chronic fatigue syndrome: A comprehensive approach to its definition and study. Ann Intern Med 1994; 121: 953-959.

6. Bakker M, Werf M-L van der. Het chronische vermoeidheidssyndroom en de arbeidsongeschiktheidsbeoordeling. Hoofddorp: TNO Arbeid, 2000.

7. Manders MJM, Nijs PAR. Het chronische vermoeidheidsyndroom. Een overschat of onderschat probleem in de praktijk van de arts voor arbeid en gezondheid. Amsterdam: NIA TNO, 1998.

8. Stroband J, Petri H, Graffelman AW, Knuistingh Neven A. Opvattingen van huisartsen over het chronisch vermoeidheidsyndroom. Afdeling Huisartsen Verpleeghuisgeneeskunde, Universiteit Leiden, 1999.

9. Blatter BM, Berg R van den, Putten, DJ van. Werk, uitval en reïntegratie bij patiënten met ME/CVS. Tijdschr Bedrijfs Verzekeringsgeneeskd 2005; 13: 198-204.

10. Vercoulen JH, Swanink CM, Zitman FG, et al. Randomised, double-blind, placebo-controlled study of fluoxetine in chronic fatigue syndrome. Lancet 1996; 347(9005): 858-861.

11. Megen-van Roo AE van, Lulofs R, Schmidt AJM, Halfens R. Chronisch vermoeidheidsyndroom: Hoe sta je er tegenover? Scriptie Med Psych en Verplegingswetenschap Universiteit Maastricht, 1995. 